\title{
Effect of Labor Turnover on Productivity In Health Institutions In Khulais Governorate - Makkah
}

\author{
Dr. ALI AHMED ALI AHMED \\ Assistant Professor, Faculty of Business Administration \\ University of Jeddah - Saudi Arabia \\ Email: abuharira@gmail.com
}

\begin{abstract}
This study was conducted in the province of Khulais Emirate of Mecca in Saudi Arabia. A case study applied to the health institutions in the province in order to study the impact of the rotation of employment on productivity in health institutions where the researcher used the descriptive analytical method, which is the scientific method that meets the purposes of the study. This method depends on the study of reality as it is on the ground and expressed in quantity and quality. In order to achieve the objectives of the study, the data were analyzed in the SPSS program. The rate of labor turnover greatly affects productivity in health institutions in Khulais governorate. Where the study sought to answer the questions related to the problem of the study: Is the increase or decrease in the rate of turnover of labor affects the productivity in the health institutions in the province of Khulais? Are there positive or negative effects of labor turnover on productivity? How many and what kind of human resources are required to work in the facility? The study aims to test the following hypotheses: Employment turnover significantly affects productivity in health institutions in Khulais governorate. There are differences, which are statistically significant at the level of the function $(0.05=\alpha)$ regarding the turnover of employment in health institutions in Khulais governorate attributed to the study variables. Differences were statistically significant at the level of function $(0.05=\alpha)$ around the level of productivity in health institutions in Khulais governorate attributed to the study variables. There is a statistically significant relationship between turnover and productivity.
\end{abstract}

Keywords: Employment Turnover, Productivity, Human Resources, Health Institutions.

\section{Introduction}

Human resources play an important role in health institutions in general, since they are more dependent on the human factor than on machinery, equipment and technology. This is why the service institutions, unlike the productive institutions of commodities, rely more on machines, machinery and technology than the human element. Therefore, any increase or decrease in the human element will be reflected positively or negatively on the production process in the health institution.

\section{Turnover}

The turnover rate (the rate of entry and exit of employees to and from one institution) indicates the average number of employees. If the turnover is $12 \%$, this means that 12 out of every 100 workers are likely to leave work, in which case the turnover rate is called the rate of leaving the service. The turnover rate can be calculated as follows:

Employment turnover $=($ number of employees leaving $/$ average number of employees $) * 100$ 
Number of Departure $=$ Number of employees at the beginning of a period - Number of employees at the end of the same period.

Note: Average number of employees $=($ number of workers first term + number of workers last period $) / 2$

\section{Productivity}

Work productivity is the sum of output at a specific time per worker. What the worker can produce in (hour, day, week, month, year, etc.) on average. Before measuring the average output of your workers, it will be necessary to choose a unit of measurement and here we will depend on the number of out-patients and beneficiaries of the health service and the number of inpatient.

Productivity $=$ Output $/$ Input

Total productivity $=$ total output $/$ total inputs

\section{Previous Studies}

This section is interested in studies and researches that dealt with the issues of labor turnover or productivity or both of them.

Faki, Aisha Faki Ekelf Faki (2002) mentioned in their study that effect of labor turnover and absence on the organization's performance. A Case study in Sudan Cotton Company, limited to the Red Sea State as a model for field study. The study aimed to identify the theoretical framework for the rotation of work, its types and importance, its effects on the level of performance, and also to identify the problems faced by the institutions in amplifying the phenomena and finding solutions to them. Al-Hussein (2011) study reached a number of results, the most important of which is the relationship between the level of turnover and the level of performance of the organization, meaning that in the case of high turnover, the performance of the organization decreases, indicating an inverse relationship between turnover and performance of the organization (Al-Tamimi 2016).

According to Abdus, Abdul \& Abdus (2011) the policy of trade openness and its role in improving productivity in Algerian institutions as a competitive indicator with a focus on the worker productivity index. This study attempts to demonstrate the role played by the policy of trade openness in Algeria, which is mainly in raising and developing competitiveness (Shaways 2004). Productivity of the work so that access to our institutions to occupy good positions in the global markets, and since export-oriented extractive industries represent a large proportion of the total Algerian exports, did those industries have a role in improving the productivity of institutions Especially in the labor productivity of this sector, and hence on its competitive position (Hassouna 2011).

The results of the study of Al-Haddad (2017) showed a clear improvement in the productivity of the industrial worker in the export industries, and because the size of employment in this sector has increased from 2000 to 2009, while at the same time the value of industrial output at an average rate and improved productivity of the industrial worker by $15 \%$ In 2008 , due to higher oil prices. This rise in productivity is reflected in per capita income (Jad 1997).

Al-Zawi and Zawi (2009) study shows that the impact of the organizational climate on the functioning of the health institutions. The study of the state of the hospital's public institution This study aims at clarifying the turnover of the work in the health institutions (Khader 2013). The questionnaire was used as a tool for study so that 251 questionnaires were distributed on a sample in General Hospital Establishment "Sulaiman Omairat in Torkat" Results of the survey were analyzed by the statistical analysis program (SPSS). AlNuaimi (2009) study concluded the following results: There are available dimensions of the organizational 
climate in the institution under study at an average level. There is also a statistically significant effect of the dimensions of the organizational climate on the turnover of the institution studying (Mill 2010).

\section{Method}

\section{Research Methodology:}

The research depends on the analytical descriptive approach based on the initial data collected through personal interviews and field visits. It also relies on secondary data such as references, research, books, periodicals and previous studies related to the research to determine the factors affecting the emergence of the problem and try to link the causes and causations. Test hypotheses and then reach the final results and propose recommendations to improve the efficiency of human resources management in the institutions under study.

\section{Data collection tools:}

The search depends on the following tools in data collection:

Primary sources include:

1. Personal interviews and field visits.

2. Observation.

Secondary sources include:

Subject literature, patient records and official reports.

\section{Search Limits}

1. Objective Limits: The study tackled the effect of labor turnover on productivity in the health institutions in Khulais Governorate - Emirate of Makkah

2. Time Limits: The research covers the stages in human resources planning and its effect on reducing the turnover rate of labor in the period from 2017 to 2018.

Spatial boundaries: The research covers objective boundaries: The research dealt with the effect of labor turnover on productivity in health institutions in Khulais Governorate - Emirate of Makkah.

\section{Study Society}

The community of the study contains the health institutions in Khulais governorate.

\section{Data}

\section{Sample Selection Method}

The researcher will select a random sample of the study population by $20 \%$ in order to harmonize the study population. It is sufficient to achieve high accuracy in the study results. The random sample of the homogeneous study group ranges from $10 \%$ to $20 \%$ of table (2), (3) and (4) ) The number of health institutions 12 institutions, the researcher will choose at least 3 institutions and meet the requirements of the study.

4-2. Methods of calculating productivity per worker and labor turnover according to the following equations: 
Productivity $=$ Output $/$ Input

Labor productivity $=$ number of consumers $/$ number of employees

Employment turnover $=($ number of employees leaving / average number of employees $) * 100$

Number of Departure $=$ Number of Employees at the Beginning of the period - Number of Employees at the End of the Period.

Average Number of Employees $=($ Number of Workers First Term + Number of Workers Last Term $) / 2$

Population in Khulais Governorate (beneficiaries of health services):

Table (1): Population Distribution in Khulais Governorate

\begin{tabular}{|l|l|l|l|l|l|l|l|l|l|}
\hline \multirow{2}{*}{$\begin{array}{c}\text { Employees } \\
\text { Governgrate }\end{array}$} & \multicolumn{2}{|l|}{ Saudis } & \multicolumn{2}{l|}{ Non-Saudis } & \multicolumn{2}{l|}{ Total } \\
\cline { 2 - 11 } & Males & Female & Total & Males & Female & Total & Males & Female & Total \\
\hline Khulais & 23515 & 25047 & 48562 & 6331 & 1794 & 8125 & 29846 & 26841 & 56687 \\
\hline
\end{tabular}

Table (1): The total population of Khulais Governorate is 56687 people, who are the beneficiaries of the provision of health services in the governorate.

Table (2): The number of hospitals in Governorate of Khulais. Hospitals in Khulais Governorate:

\begin{tabular}{|c|c|c|}
\hline The name of the health unit & Number of hospitals & Number of beds \\
\hline Khulais General Hospital & 1 & 50 \\
\hline
\end{tabular}

Table (2): We note that there is only one hospital in Khulais governorate despite the large number of people in this governorate according to table 1 in addition to serving the road between the Emirate of Mecca and Medina, a religious area visited by a large number of pilgrims and visitors, This in turn adversely affects the quality of services provided within the hospital.

Table (3): Primary Health Care (PHC) Centers in Khulais Governorate Primary Health Care Centers in Khulais Governorate:

\begin{tabular}{|c|c|}
\hline Unit name by region & Number of units \\
\hline Khulais (center) & 3 \\
\hline Al Zabiuh and al Juma'ah & 1 \\
\hline Wadi qadid & 1 \\
\hline Om aljiram & 1 \\
\hline Alkhawaar & 1 \\
\hline Albarzuh & 1 \\
\hline Sitara &
\end{tabular}

From Table (3): We note that the number of primary health care centers is one center in each district within the governorate except the center has 3 (PHC) centers. In four centers there is only one doctor in each center. This means that in cases of sudden departure productivity will be greatly affected.

Table (4): Ambulance and Red Crescent Centers in Khulais Governorate.

Ambulance and Red Crescent Centers:

\begin{tabular}{|c|c|}
\hline Unit name by region & Number of units \\
\hline Wadi qadid & 1 \\
\hline Sitara & 1 \\
\hline
\end{tabular}


Table (4): There are two centers of ambulance and Red Crescent in addition to the ambulance of the government hospital.

Table (5): Health clinics in the governorate.

Private Clinics:

\begin{tabular}{|c|c|}
\hline Unit name by region & Number of units \\
\hline Khulais (center) & 2 \\
\hline
\end{tabular}

Health units that do not exist in Khulais governorate and are located in a large number of governorates of the Kingdom:

Table (6): Health units not available in the governorate.

\begin{tabular}{|l|l|}
\hline Unit name & Notes \\
\hline Health points & Non \\
\hline Endemic Disease Control & Non \\
\hline Quarry & Non \\
\hline Malaria Station & Non \\
\hline Hospitals & Non \\
\hline
\end{tabular}

The study sample: Methods of calculating productivity per worker and labor turnover according to the following equations:

Productivity $=$ Output $/$ Input

Labor productivity = number of services consumers/ number of employees

Employment turnover $=($ number of employees leaving $/$ average number of employees $) * 100$

Number of Departure $=$ Number of Employees Beginning of Term - Number of Employees End of Period. Average Number of Employees $=($ Number of Workers First Term + Number of Workers Last Term $) / 2$ Khulais General Hospital:

Table (7): Number of consumers and employees at Khulais General Hospital, for three consecutive years.

\begin{tabular}{|c|c|c|c|}
\hline & year of 2016 & year of 2017 & Year of 2018 \\
\hline Number of consumers & 63000 & 60000 & 55000 \\
\hline Number of employees & 300 & 340 & 340 \\
\hline
\end{tabular}

Table (7): We find productivity per worker and turnover rate for 2017 and 2018 in Khulais General Hospital

Table (8): Calculation of the turnover rate and productivity of each worker in Khulais General Hospital, 2017-2018.

Calculation of the turnover rate of employment and productivity at Khulais General Hospital:

\begin{tabular}{|c|c|c|}
\hline & year of 2017 & Year of 2018 \\
\hline The productivity level of the worker & 176.5 & 161.8 \\
\hline Employment turnover & $-12.5 \%$ & $\% 0$ \\
\hline
\end{tabular}

Table (9): Number of consumers and employees of Al Zabiuh and al juma'ah PHC center for three consecutive years.

Al Zabiuh and al Juma'ah Clinics:

\begin{tabular}{|c|c|c|c|}
\hline & Year of 2016 & Year of 2017 & Year of 2018 \\
\hline Number of consumers & 115.200 & 114.300 & 100.250 \\
\hline Number of employees & 20 & 22 & 31 \\
\hline
\end{tabular}


From Table (9): we can calculate the productivity of each worker and the turnover rate for the years 2017 and 2018 in the primary health care center of the Al Zabiuh and al Juma'ah.

Calculation of the turnover rate of employment and productivity in the primary health care center in $\mathrm{Al}$ Zabiuh and Al Juma'ah:

Table (10): Calculation of the turnover rate and the productivity of each worker at the PHC center of $\mathrm{Al}$ Zabiuh and al Juma'ah for the years 2017-2018.

\begin{tabular}{|c|c|c|}
\hline & Year of 2017 & Year of 2018 \\
\hline The productivity level of the worker & 5.2 & 3.2 \\
\hline Employment turnover & $\%-0.095$ & $\%-0.34$ \\
\hline
\end{tabular}

Table (11): Number of consumers and employees of the primary health care clinic in Wadi qadid for three consecutive years.

Primary Health Care Clinic in Wadi Qadid:

\begin{tabular}{|l|c|c|c|}
\hline & Year of 2016 & Year of 2017 & Year of 2018 \\
\hline Number of consumers & 8896 & 10745 & 12983 \\
\hline Number of employees & 12 & 15 & 17 \\
\hline
\end{tabular}

Table (11): We find the productivity of each worker and the turnover rate for the years 2017 and 2018 in the primary health care clinic in Wadi qadid.

Table (12): Calculation of the turnover rate and productivity of each worker in the primary health care clinic in Wadi qadid for the years 2017-2018.

Calculate the turnover rate of labor and productivity in the Primary Health Care Clinic in Wadi Qadid:

\begin{tabular}{|c|c|c|}
\hline & Year of 2017 & Yea of 2018 \\
\hline The productivity level of the worker & 716.3 & 763.7 \\
\hline Employment turnover & $\%-22.2$ & $-11.76 \%$ \\
\hline
\end{tabular}

Note: The negative sign in Table (8), (10) and (12) means that there is additional employment at the end of the period (ie, there is no job leave but adding employment at the end of the period)

Results and discussion of hypotheses:

\section{First Hypothesis:}

The rate of turnover of labor significantly affects productivity in health institutions in Khulais Governorate.

Table (13): The effect of the rate of labor turnover on productivity.

\begin{tabular}{|ll|c|c|}
\hline & & Employment turnover & Productivity level \\
\hline Employment turnover & Pearson Correlation & 1 & $-.808-$ \\
& Sig. (2-tailed) & & .052 \\
& $\mathrm{~N}$ & 6 & 6 \\
\hline Productivity level & Pearson Correlation & $-.808-$ & 1 \\
& Sig. (2-tailed) & .052 & \\
& $\mathrm{~N}$ & 6 & 6 \\
\hline
\end{tabular}

From Table (13), Pearson correlation coefficient was found to establish the relationship between the turnover rate and the productivity of the health institutions in Khulais governorate. The results are shown in 
Table (13) which shows that the correlation coefficient value is -0.808 and the mean level is 0.052 which equals 0.05 . This confirms the acceptance of the hypothesis and there is a positive correlation relationship with a statistical significance of a direct link between the turnover of employment and productivity in health institutions in the province of Khulais.

\section{Second Hypothesis:}

There are statistically significant differences at the level of function $(0.05=\alpha)$ around the level of turnover of workers in health institutions in Khulais governorate.

Table (14): shows the differences on the turnover of employment in health institutions in Khulais

Governorate

Differences in turnover

\begin{tabular}{|c|c|c|c|c|c|c|}
\hline & \multicolumn{6}{|c|}{ Test Value $=0$} \\
\hline & \multirow[b]{2}{*}{$\mathrm{T}$} & \multirow[b]{2}{*}{ Df } & \multirow{2}{*}{$\begin{array}{l}\text { Sig. (2- } \\
\text { tailed) }\end{array}$} & \multirow{2}{*}{$\begin{array}{c}\text { Mean } \\
\text { Difference }\end{array}$} & \multicolumn{2}{|c|}{$\begin{array}{c}\begin{array}{c}95 \% \text { Confidence Interval of } \\
\text { the Difference }\end{array} \\
\end{array}$} \\
\hline & & & & & Lower & Upper \\
\hline $\begin{array}{l}\text { Primary health } \\
\text { care center (Wadi } \\
\text { qadid) }\end{array}$ & 3.253 & 1 & .190 & 16.98000 & -49.3464 & 83.3064 \\
\hline $\begin{array}{l}\text { Primary health } \\
\text { care center (Al } \\
\text { Zabiuh and Al } \\
\text { Juma'ah) }\end{array}$ & 1.776 & 1 & .327 & .21750 & $-1.3390-$ & 1.7740 \\
\hline $\begin{array}{l}\text { Khulais General } \\
\text { Hospital }\end{array}$ & 1.000 & 1 & .500 & 6.25000 & -73.1638 & 85.6638 \\
\hline
\end{tabular}

Note from table (14) The significance value of the primary health care center is equal to 0.190 (P-Value $=$ $0.190>0.05$ ), which leads us to accept the null hypothesis at the level of function 5\%, i.e. there are no significant differences in the turnover rate of the primary care center, The mean value of the primary care center is $0.327(\mathrm{P}$-Value $=0.327>0.05)$ which leads us to accept the null hypothesis at the level of $5 \%$. There is no significant difference in the turnover rate of the primary health care center. The significance value of khulais general hospital is 0.005 ( $\mathrm{p}$-value $=0.500>0.05$ )), which leads us to accept the null hypothesis at the level of function $5 \%$, i.e. there are no significant differences in the turnover rate of employment at Khulais General Hospital. However, there are significant differences between these institutions. This reinforces the hypothesis that there are differences of statistical significance regarding the labor turnover at the level of health institutions in Khulais governorate due to the variables of the study.

\section{Third Hypothesis}

There are statistically significant differences at the level of the function $(0.05=\alpha)$ about the level of productivity in the health institutions in Khulais governorate.

Note from table (15) that the significance value of the primary health care center (wadi Gadid) is equal to 0.020 (P-Value $=0.020<0.05)$, which leads us to reject the null hypothesis at the level of function $5 \%$, i.e. there are significant differences in the level of productivity of the worker in that primary health care center. The significance value of the primary health care center (Al Zabiuh and Al Juma'ah) is 0.149 (P-Value = $0.149>0.05$ ), which leads us to accept the null hypothesis at the level of 5\%. There is no significant difference in the level of productivity of the worker in the primary health care center. The significance value of Khulaise General Hospital is $0.028(\mathrm{P}$-Value $=0.028<0.05)$ ) leads us to reject the null hypothesis with a function level of $5 \%$, i.e. there are significant differences in the level of productivity of the worker at 
Khulais General Hospital. While there are significant differences between these health institutions, and this strengthens the hypothesis that there are differences of statistical significance on the level of productivity in health institutions in the province of Khulais attributed to the variables of the study.

Table (15): The differences in the level of productivity in health institutions in Khulais Governorate Differences in productivity level

\begin{tabular}{|c|c|c|c|c|c|c|}
\hline & \multicolumn{6}{|c|}{ Test Value $=0$} \\
\hline & \multirow[b]{2}{*}{$\mathrm{T}$} & \multirow[b]{2}{*}{ Df } & \multirow{2}{*}{$\begin{array}{l}\text { Sig. }(2- \\
\text { tailed) }\end{array}$} & \multirow{2}{*}{$\begin{array}{c}\text { Mean } \\
\text { Difference }\end{array}$} & \multicolumn{2}{|c|}{$\begin{array}{l}95 \% \text { Confidence Interval of } \\
\text { the Difference }\end{array}$} \\
\hline & & & & & Lower & Upper \\
\hline $\begin{array}{l}\text { Primary health care center } \\
\text { (Wadi qadid) }\end{array}$ & $\begin{array}{r}31.2 \\
24\end{array}$ & 1 & .020 & 740.00000 & 438.8629 & 1041.1371 \\
\hline $\begin{array}{l}\text { Primary health care center } \\
\text { (Al Zabiuh and Al } \\
\text { Juma'ah) }\end{array}$ & $\begin{array}{r}4.20 \\
0\end{array}$ & 1 & .149 & 4.20000 & $-8.5062-$ & 16.9062 \\
\hline Khulais General Hospital & $\begin{array}{r}23.0 \\
14\end{array}$ & 1 & .028 & 169.15000 & 75.7594 & 262.5406 \\
\hline
\end{tabular}

\section{Fourth Hypothesis}

There is a statistically significant correlation between labor turnover and productivity. From Table 13, Pearson correlation coefficient was found to establish the correlation between productivity and labor turnover. The results are shown in Table (13) which shows that the value of the coefficient of correlation between productivity and labor turnover is $\mathrm{R}=-0.808$. The significance level is 0.052 which is equal to the $\mathrm{P}$-Value (0.05). this confirms the acceptance of the hypothesis i.e. there is a very strong positive correlation with a direct statistical significance linking the rate of turnover of employment and the level of productivity.

\section{Results}

- The rate of turnover of labor significantly affects productivity in health institutions in Khulais governorate.

- Increasing or decreasing the rate of employment turnover affects the productivity in the health institutions in Khulais Governorate.

- There is great importance to the human element in the health institutions where the dependence is heavily on the human element over the equipment.

- Productivity is important in health institutions where increased productivity plays a major role in achieving health institution goals.

- There are statistically significant differences at the level of function $(0.05=\alpha)$ around the level of turnover of employment in the health institutions in Khulais governorate attributed to the study variables.

- There are statistically significant differences at the level of function $(0.05=\alpha)$ around the level of productivity in the health institutions in Khulais governorate attributed to the study variables.

- There is a very strong correlation relationship, a positive statistical indication linking the rate of turnover and productivity.

\section{Recommendations}

- Good moral and financial incentives must be put in place to reduce the rate of leaving work.

- Health institutions must create a good working environment to increase the productivity of employees

- The high rate of leaving the service is an indicator of low satisfaction and morale, health institutions must follow policies to achieve job satisfaction, which reflects positively on the self-esteem of workers. 
- Working to increase the profile of human resources management awareness to preserve the human element.

- Human resource management in health institutions should be familiar with the methods of reducing the rate of leaving work and benefiting from external expertise.

\section{References}

Abdus, Abdul Aziz Abdus (2011). The policy of opening up trade and its role in improving productivity in Algerian enterprises as a competitive indicator with a focus on the worker productivity index. (University of Bashar, Algeria: unpublished MA study).

Al-Haddad, Noor Hatem Al-Haddad (2017). Principles of Determination of Sample Size (Baghdad: College of Physical Education and Sports Science for Girls / University of Baghdad).

Al-Hussain, Mohammed Ebdoye Al-Hussein (2011). Production and Operations Management (Amman: Dar Al-Mahaa for Publishing and Distribution).

Al-Naimi, Jalal Mohammed Al-Nuaimi (2009). Department of Labor in Production and Operations Management (Amman: Ithraa Publishing and Distribution).

Al-Tamimi, Abdullah Hussein Al-Tamimi (2016). Production and Process Management Kamel Entrance (Amman: Dar Al Fikr Publishing and Distribution).

Al-Zawi, Halima bin Zawi (2009). The impact of the organizational climate on the functioning of the health institutions. (University of Qadi Marabah: unpublished study).

Faki, Aisha Faki Ekelf Faki (2002). Effect of turnover and absence on the performance of the organization Case study at Sudan Cotton Company Limited in the State of the Sea (Red Sea University: unpublished MA study). General Organization for Statistics in Saudi Arabia (https://www.stats.gov.sa).

Hassouna, Faisal Hassouna (2011). Human Resource Management (Amman: Dar Osama for Publishing and Distribution). Health records for each health institution in question. Human resources department for each of the health institutions under study.

Jad, Mohamed Sayed Jad (1997). Production and Operations Management (Amman: Dar Al Fikr for Printing)

Khader, Ahmed Ibrahim Khader (2013). Easy rules for sample size selection (Dr. Ahmed Ibrahim Khader site / Thesis Industry, https://www.alukah.net/web/khedr/0/51829).

Mill, Zakaria Mill (2010). Production, Operations and Total Quality Management (Alexandria: Dar Al Wafaa Printing \& Publishing). Official reports of each of the health institutions under study.

Shaways, Mustafa Najib Shaways (2004). Human Resources Management (Jordan: Dar Al Shorouk Publishing \& Distribution). 